SHIFTING BASELINES 



\section{Shifting Baselines}

THE PAST AND THE FUTURE OF OCEAN FISHERIES

EDITED BY

Jeremy B. C. Jackson, Karen E. Alexander, and Enric Sala

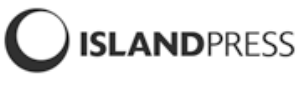

Washington | Covelo | London 
Copyright (C) 2011 Island Press

All rights reserved under International and Pan-American Copyright Conventions. No part of this book may be reproduced in any form or by any means without permission in writing from the publisher: Island Press, 1718 Connecticut Avenue NW, Suite 300, Washington, DC 20009

Island Press is a trademark of The Center for Resource Economics.

Figures designed by Sherry Palmer

Library of Congress Cataloging-in-Publication Data

Shifting baselines : the past and the future of ocean fisheries / edited by Jeremy B.C. Jackson Karen Alexander, and Enric Sala.

p. $\mathrm{cm}$.

Includes bibliographical references and index.

ISBN-13: 978-1-61091-000-2 (hardback)

ISBN-10: 1-61091-000-1 (cloth)

ISBN-13: 978-1-61091-001-9 (paper)

1. Fisheries-History. 2. Fishery management. I. Jackson, Jeremy B. C., 1942-

II. Alexander, Karen, 1951 III. Sala, Enric.

SH211.S45 2011

$338.3^{\prime} 727-\mathrm{dc} 22$

2011005032

Printed on recycled, acid-free paper

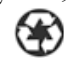

Manufactured in the United States of America

10987654321

Keywords: fisheries management, marine ecosystems, biodiversity, historical ecology, maximum sustainable yield, fishing down the food web, anchovy, sardine, cod 


We dedicate this book to our friend and colleague Daniel Pauly for his fundamental insight in how problems of shifting baselines shape and distort our lives. 

Chapter 1 A Shoreline Remembrance CARL SAFINA

Chapter 2 The "March of Folly" in Global Fisheries U. RASHID SUMAILA AND DANIEL PAULY

Chapter 3 If a Frond Falls in the Kelp Forest (does it make any sound?) RANDY OLSON

PART II ANCHOVIES AND SARDINES

Chapter 4 The Sardine-Anchovy Puzzle ALEC D. MACCALL

Chapter 5 Variations in Fisheries and Complex Ocean Environments

DAVID B. FIELD, FRANCISCO CHAVEZ, CARINA B. LANGE, AND PAUL E. SMITH

PART III COD

Chapter 6 The Historical Abundance of Cod on the Nova Scotian Shelf

W. JEFFREY BOLSTER, KAREN E. ALEXANDER, AND WILLIAM B. LEAVENWORTH

Chapter 7 History and Context: Reflections from Newfoundland DANIEL VICKERS, WITH LOREN MCCLENACHAN 
Chapter 8 Uncovering the Ocean's Past

HEIKE K. LOTZE, JON M. ERLANDSON, MARAH J. HARDT, RICHARD D. NORRIS, KAUSTUV ROY, TIM D. SMITH, AND CHRISTINE R. WHITCRAFT

Chapter 9 Whales, Logbooks, and DNA

STEPHEN R. PALUMBI

\section{PART V FROM FISHERIES MANAGEMENT} TO ECOSYSTEMS

Chapter 10 Management in the Gulf of Maine

ANDREW A. ROSENBERG, KAREN E. ALEXANDER, AND JAMIE M. COURNANE

Chapter 11 Lessons from Coral Reefs ENRIC SALA AND JEREMY B. C. JACKSON

Chapter 12 Epilogue: Shifting Baselines for the Future

JEREMY B. C. JACKSON AND KAREN E. ALEXANDER

Notes

Contributors

Index 